\title{
BOEKBESPREKING: \\ Chinese armorial porcelain for the Dutch Market
}

In 1733 voer het schip Nieuwvliet voor de VOC-kamer van Zeeland rechtstreeks van Kanton naar Middelburg. Maar liefst zes opvarenden hadden één of zelfs meer wapenserviezen gekocht die ze als onderdeel van hun particuliere bagage mee naar huis brachten. Wellicht was dit enthousiasme ingegeven door de nieuwe organisatie van de China-handel. Pas sinds 1729 had de VOC een vestiging in Kanton en werd porselein en andere handelswaar in China zelf besteld en ingekocht zodat gemakkelijker en met een nauwkeuriger toezicht porselein met bijzondere voorstellingen besteld konden worden. Dit wapenporselein, beschilderd in famille rose-kleuren, en van een hoge kwaliteit, behoort tot een eerste bloeiperiode van het Nederlandse wapenporselein. In de loop van de $18^{\mathrm{e}}$ eeuw zouden zelfs ongeveer 700 van dergelijke serviezen door Nederlanders besteld worden. Niet alleen in Nederland viel het fraaie wapengoed op. Ook in andere landen, met name Engeland, werd het gewaardeerd en zou de mode in de loop van de $18^{\mathrm{e}}$ eeuw voorschrijven dat elke zichzelf respecterende familie zijn wapenservies bestelde. In Engeland waren het er uiteindelijk zo'n 5000.

Jochem Kroes, medewerker van het Centraal Bureau voor Genealogie, heeft een fantastisch boek geschreven over Chinees wapenporselein voor de Nederlandse markt. Het boek is zeer omvangrijk - het heeft een royaal formaat en maar liefst 720 pagina's. Daarin worden de 455 serviezen die Kroes heeft kunnen vinden uitvoerig beschreven en geillustreerd. De ordening volgt in grote lijnen het standaardwerk van David Howard over Chinees porselein met Engelse wapens (Chinese armorial porcelain, Londen, 1974/2003) en dat is waarschijnlijk de verstandigste keuze om de gebruiker van het boek in staat te stellen om met een onbekend wapenbord in de hand bij de juiste beschrijving uit te komen.

Allereerst moet opgemerkt worden dat Kroes er in geslaagd is een bijzonder groot aantal serviezen (of losse onderdelen daarvan natuurlijk) terug te vinden. Veel meer dan hij bij aanvang van het onderzoek verwachtte aan te treffen. Uit de grote lijst met personen en instellingen die in het voorwoord bedankt worden, blijkt dat hij bij 'iedereen' is langs geweest. Het zal niet eenvoudig zijn het $456^{\mathrm{e}}$ stuk wapenporselein te vinden. Zelf schat Kroes dat er ooit ongeveer 700 serviezen geweest zullen zijn.

De entries van de catalogus bevatten een beschrijving van het porselein en van het wapen dat er op voorkomt. Vervolgens - en dat vooral is de kracht van het boek - staan in elke entry uitstekende uiteenzettingen over de familie voor wie het porselein gemaakt is. Hier komt het wel en wee van de familie zelf ter sprake en vooral ook de carrières van leden van de familie die werkten voor de VOC in Indië of voor een van de kamers in Nederland en die

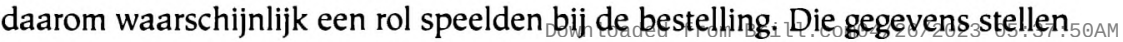
Kroes in staat het porselein in veel gevallen nauwkeurig te dateren. Hef bijftcess 


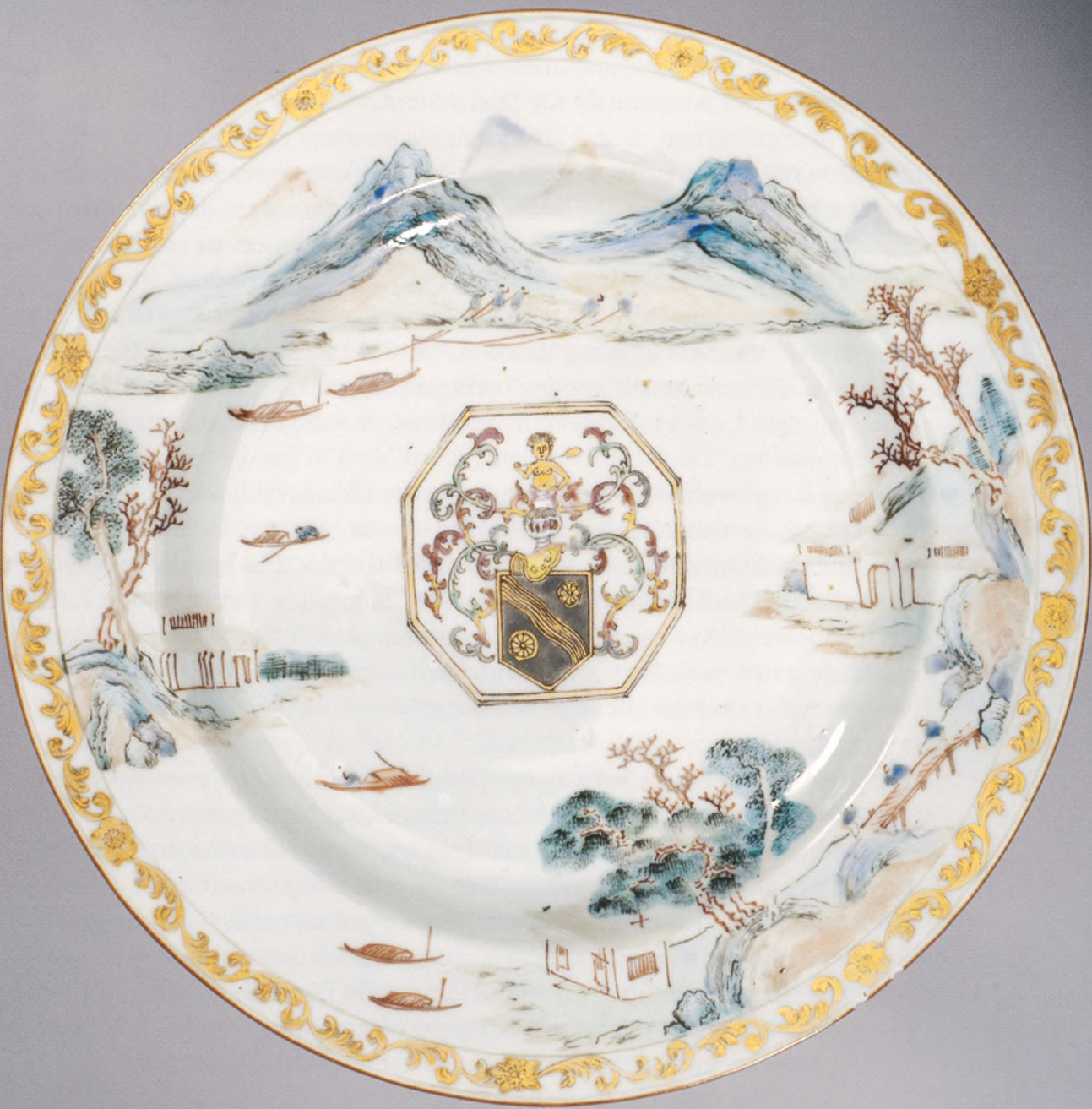

Afteelding uit het

besproken boek

Chinese armorial

porcelain for the

Dutch Market 
wel zaak de catalogusbeschrijvingen goed te lezen. Als een familielid een tijd in Indië gewerkt heeft, wordt aangenomen dat het porselein rond diens vertrek besteld is en meegenomen naar huis (bijvoorbeeld nr. 424). Maar of dat altijd zo ging, is niet zeker zoals Kroes zelf elders aangeeft: de van Hardenbroeken kregen van een relatie in Indië wapenporselein toegestuurd in gepermitteerde kistjes (nr. 379) zo blijkt uit de interessante correspondentie die Kroes ons presenteert, en dat kan vaker zijn gebeurd. De dateringen op grond van de familiegeschiedenis zijn dus altijd zeer aannemelijk, maar staan niet onomstotelijk vast. Ook als er geen historische aanwijzingen zijn, durft Kroes het porselein op stilistische gronden scherp te dateren, op vijf of tien jaar. Niet alleen dient de familiegeschiedenis om het porselein te dateren, omgekeerd wordt de precieze datering op grond van stijlkenmerken gebruikt om vast te stellen welk familielid of welke relatie het porselein besteld kan hebben (zie bijvoorbeeld nr. 13). Uit het boek spreekt niet alleen het kennerschap van de genealoog, maar ook van de porseleinkenner.

Omdat zoveel wapenporselein is teruggevonden en de families die het porselein bestelden zoveel aandacht krijgen, ontstaat een interessant inzicht in de netwerken en verknopingen van familiebanden en patronages van mensen die op de een of andere manier aan de VOC verbonden waren. Praktische gegevens over het porselein en referenties zijn achter in het boek verwerkt in de rubriek 'references of the Catalogue'. Dit biedt niet alleen bruikbare ingangen om nog meer informatie te vinden over meest interessante opdrachtgevers van het wapengoed, Kroes geeft ook zeer uitvoerig aan waar zich andere serviesonderdelen bevinden met hetzelfde wapen en - zo mogelijk - waar het is gepubliceerd.

De afbeeldingen in het boek zijn redelijk tot goed en dat mag een grote prestatie heten. Juist de compleetheid maakt het boek zo waardevol en dat betekent natuurlijk dat Kroes niet alleen nieuwe of recente foto's kon gebruiken, maar soms ook genoegen moest nemen met bijvoorbeeld reproducties uit oude handelaren- en veilingcatalogi. Met gebruikmaking van moderne technische middelen zijn ook die laatste redelijk gereproduceerd.

Aan de catalogus gaan uitvoerige inleidingen vooraf over de decoratietypen, de vormen, de heraldische beschilderingen en over de families die het porselein bestelden. Deze inleidingen zijn tegelijkertijd een analyse van de gegevens die in het catalogusdeel gepresenteerd worden. Dat is wellicht vanzelfsprekend, maar voor de leesbaarheid van de inleidingen is dat niet altijd gelukkig. Door de grote hoeveelheid feiten en feitjes (in de trant van: 'in Nederland had $4 \%$ van de serviezen een rouge de fer decoratie, in Engeland $4,4 \%$ '; en 'voor zover bekend werden elf serviezen besteld ter gelegenheid van een koperen bruiloft en tien voor een zilveren') krijgen de inleidingen niet veel vaart, zeker in vergelijking met alle zeer lezenswaardige petites histoires in de catalogus. Bovendien lijken al die gegevens zeer exact, maar is de betekenis ervan betrekkelijk, aangezien Kroes er elders op wijst dat er nog zo'n 250 serviezen níet gevonden zijn, waardoor de percentages toch weer net anders kunnen zijn. In de inleidingen wordt deels verwezen met behulp van voetnoten, maar deels ook wordt naar een catalogusnummer verwezen. In die catalogusbeschrijvingen wordt vervolgens verwezen naar de omvangrijke sectie 'references of the Catalogue' die afgekorte titelbeschrijvingen bevat die uiteindelijk in de, in verschillende onderdelen uiteenvallende, literatuurlijsten en afkortingenlijsten terug te vinden zijn Dat is $_{\mathrm{b}}$ een heel geblader. Het boek heeft zeer uitvoerige indexen, één op serviezen en één algemene access 
index. Daarin staat - zoals uit het bovenstaande te verwachten is - een grote hoeveelheid sjieke, veelal aan de VOC gelieerde $18^{\mathrm{e}}$-eeuwers. Voor mensen die in deze personen zijn geïnteresseerd zal deze publicatie een handboek zijn dat men steeds onder handbereik wil hebben.

- Jochem Kroes

Chinese Armorial Porcelain for the Dutch Market

Waanders, 2007

720 pagina's, zeer rijk geillustreerd

ISBN 9789040083310 